\title{
Conceptualizing Terrorism
}

\section{Introduction}

It is widely recognised that defining terrorism has been an issue that has confounded policymakers and academics alike. For some, such definitional exploits are not worth the effort as the prospects for a universally agreed definition are remote indeed. While there have always been very good reasons for aspiring to reach such a definition from both a policymaking and an academic perspective, this article argues that there are further reasons for doing so in the post-9/11 environment. It will then propose three preliminary assumptions when approaching the definitional problem - that there is no such thing as an act of violence that is in and of itself inherently terrorist, that terrorism is best conceptualized as a particular method of political violence rather than defined as inherent to any particular ideology or perpetrator, and that non-civilians and combatants can also be victims of terrorism. The article will then draw out the implications that these assumptions have for the definitional debate.

\section{The need to re-focus on the definition?}

There have always been good reasons for attempting to generate a universally agreed definition of terrorism. From a policymaking perspective the most important of these have been to do with the facilitation of international cooperation against the phenomenon, ${ }^{1}$ while from an academic perspective there has been an acknowledged need to advance theoretical development as to 'what terrorism is'. Often used as a perjorative label, a common and formidable obstacle to an agreed definition has been its subjective application (or nonapplication) according to where one's interests lie, and this has obfuscated a more dispassionate and analytical approach.

Even before 9/11 '[t] he term terrorism [was] so widely used in many contexts as to become almost meaningless', , while Conor Gearty remarked in 1991 that ' $[\mathrm{t}]$ he word resonates with moral opprobrium and as such is, as far as the authorities and others are concerned, far too useful an insult to be pinned down and controlled'3. Yet, since the events of September 2001

\footnotetext{
${ }^{1}$ See, for example, Alex P. Schmid, 'Terrorism - The Definitional Problem', Case Western Reserve Journal of International Law, Volume 36, Nos. 2 and 3, 2004, pp. 379-80, adapted from: Boaz Ganor, 'Defining Terrorism: Is One Man's Terrorist Another Man's Freedom Fighter?', International Institute for CounterTerrorism, August 1998, webpage: http://www.ict.org.il/ResearchPublications/tabid/64/Articlsid/432/Default.aspx (accessed November 6th 2013); European Commission Sixth Framework Programme Project, 'Defining Terrorism' (WP3 Deliverable 4), October $1^{\text {st }}$ 2008, available at: http://www.transnationalterrorism.eu/tekst/publications/WP3\%20Del\%204.pdf (accessed November $6^{\text {th }} 2013$ ).

${ }^{2}$ Richardson, L., 'Terrorists as Transnational Actors', Taylor, M., and Horgan, J. (eds.), The Future of Terrorism, Frank Cass, 2000, p. 209.

${ }^{3}$ Gearty, C., Terror, Faber and Faber, London, 199, p. 6.
} 
it has been employed so widely and carelessly in public and political discourse that there appears to be a wholesale disregard for any serious endeavour to treat terrorism as an analytical concept. Richard English, in his incisive work on how to respond to terrorism, argued that the subjective use of the term has meant that 'one can end up merely with antiphonally chanted, mutually echoing abuse, and as a result with little clarity or analytical illumination.' 4

'Terrorism' has been coined to refer to protestors in Thailand, Tunisia and Libya ${ }^{5}$, to the Israeli attack on a flotilla of ships attempting to break the Israeli blockade of Gaza, to the US invasion of Iraq and the Israeli invasion of Lebanon, ${ }^{6}$ to US drone attacks in Pakistan, to Western and NATO airstrikes against Libya, to Syrian rebels attempting to overthrow the Assad regime, and to Wikileaks founder Julian Assange who was described by US Senator Mitch McConnell as a 'high-tech terrorist'. 'Whether or not any or all of these should be classified as terrorism (or terrorists) the point is that the label is all too often used without any real rigour as to what terrorism is and what its parameters are. Martha Crenshaw, a respected scholar in the field, has argued that 'the term is often used in a careless or perjorative way for rhetorical reasons', ${ }^{8}$ while a UN High Level Panel in 2004 lamented that 'a lack of agreement on a clear and well known definition undermines the moral and normative stance against terrorism and has stained the United Nations image'.

The failure to craft an agreed definition of terrorism has left a vacuum for actors, whether they be state or non-state, to define terrorism in ways that serve their own perceived political and strategic interests, and, in the case of state responses, remits of 'counter-terrorism' are often determined accordingly. As one observer has noted 'the more confused a concept, the more it lends itself to opportunistic appropriation'. ${ }^{10}$ This undermines attempts to generate international cooperation against terrorism and can lead to unilateral and (even if unwittingly) counter-productive strategies. Indeed, some have suggested that the failure to define the concept is itself a cause of terrorism. Schmid, for example, has argued that 'a lack of definition is perceived widely as one of the factors likely to encourage future terrorism', and cites a study that places the absence of such a definition at the top of a list of ten factors and conditions 'likely to encourage future terrorism'. ${ }^{11}$

\footnotetext{
${ }^{4}$ English, R., Terrorism, How to Respond, Oxford University Press, 2009, p. 19.

${ }^{5}$ A Libyan government statement in February 2011 reportedly described protestors as "terrorist gangs made up mostly of misguided youths", who had been exploited and fed "hallucinogenic pills" by people following foreign agendas. See 'Libyan leader Muammar Gaddafi appears on state TV', BBC News, February $11^{\text {th }} 2011$, available at http://www.bbc.co.uk/news/world-africa-12533069 (accessed November 6th 2013).

${ }^{6}$ Schmid, A., (ed.), The Routledge Handbook of Terrorism Research, Routledge, London and New York, 2011, p. 88 .

${ }^{7}$ See, for example, Chittal, N., 'Sen. Mitch McConnell: Julian Assange is a "High Tech Terrorist", Mediaite website, December $5^{\text {th }} 2010$, available at: http://www.mediaite.com/tv/mitch-mcconnell-julian-assange-is-ahigh-tech-terrorist/ (accessed November $6^{\text {th }} 2013$ ).

${ }^{8}$ Crenshaw, M., Explaining Terrorism, Causes, Processes and Consequences, Routledge, 2011, p. 206.

${ }^{9}$ Report of the Secretary-General's High Level Panel on Threats, Challenges and Change, December $2^{\text {nd }} 2004$, p. 48, available at: http://www.unrol.org/doc.aspx?n=gaA.59.565 En.pdf (accessed November 6th 2013).

${ }^{10}$ Saul, B., Defining Terrorism in International Law, Oxford University Press, 2006, p. 3.

${ }^{11}$ Op. cit. Schmid, A., 'Terrorism - The Definitional Problem', p. 378 (note 1).
} 
From a legal perspective, Golder and Williams argued for the need to 'describe the concept with as much precision as possible. One danger is that if terrorism is not so defined, the powers of the State may extend very far indeed', ${ }^{12}$ while it has also been suggested that 'the absence of an internationally accepted definition of terrorism has led to international lawlessness and unilateral vigilantism. ${ }^{13}$ At the very least, then, the failure to define terrorism, both in academia and policymaking, has made its own contribution to dubious counter-terrorism responses. The first reason, then, for persisting with the definition of terrorism, or at least an agreed conceptualization of the term, is that the term has more than ever before been open to abuse. Indeed, 'the post-9/11 response to terrorism has been both analytically and practically flawed in a very dangerous manner' and this analytical failure has 'significantly exacerbated' the failures in the practical realm. ${ }^{14}$

While legal practitioners call for a precise definition in order to prosecute terrorist crimes it is the political abuse of the term that has taken on profound and ominous proportions since 9/11, and the nature of legislative responses are but one symptom of this. In $2004 \mathrm{Sami}$ Zeidan cautioned that 'the political value of the term currently prevails over its legal one ... leaving the [then] war against terrorism selective, incomplete and ineffective. ${ }^{15}$ Charles Townshend argued that 'the indefinite reach of President Bush's 'war against terror' underlined more sharply than ever the need for some definition - or compartmentalization of this manipulable term. ${ }^{16}$ For the concept has indeed been available as a 'free for all' label for any actor who wishes to denounce the activities of their political adversaries for as long as there is no general conviction as to what terrorism really means or what its parameters are.

The second reason for persevering with the definition of terrorism is that, within academia, the phenomenon is seen as something in its 'pre-theory stage' or to put it more candidly as something that 'is widely recognized as theoretically impoverished" ${ }^{17}$, even in the contemporary context of what is otherwise a burgeoning literature on terrorism since 9/11. The lack of theoretical endeavour as to 'what terrorism is' has rendered much of terrorism research as foundationally weak. Silke outlines the academic benefits of achieving consensus on the meaning of the concept:

'An agreed definition allows the research world to develop shared methods, approaches, benchmarks and appropriate topics for study. Without a definition, the

\footnotetext{
${ }^{12}$ Golder, B. And Williams, G., 'What is Terrorism - Problems of Legal Definition', University of New South Wales Law Journal, Volume 27, Issue 2, 2004, p. 272.

${ }^{13}$ Acharya, U., 'War on Terror or Terror Wars: The Problem in Defining Terrorism', Denver Journal of International Law and Policy, Volume 37, Issue 4, 2008-2009, p. 678.

${ }^{14}$ Op. cit. English, R. pp. ix-x (note 4).

${ }^{15}$ Zeidan, S., 'Desperately Seeking Definition: The International Community's Quest for Identifying the Specter of Terrorism', Cornell International Law Journal, No. 36 (2003-2004), pp. 491-2.

${ }^{16}$ Townshend, C., Terrorism, A Very Short Introduction, Oxford University Press, 2002, p. 2.

${ }^{17}$ Crenshaw, M., 'Current Research on Terrorism: The Academic Perspective', Studies in Conflict and Terrorism, Volume 15, No. 1, 1992, p. 1.
} 
focus of the field is scattered and fragmented, and an unrealistic range of activities, phenomena and actors have been labelled as terrorist. ${ }^{118}$

It therefore seems strange that there has been such scant attention on the definitional issue in research on terrorism. Silke, in his analysis of the main academic terrorism journals in the period 1990-99, found that '[o]f the 490 articles published in the ten-year period, just eight (1.6 per cent) could be regarded as primarily conceptual papers' ${ }^{19}$, while in the period $2000-7$ 'there were only seven articles on definitional aspects'. ${ }^{20}$ Another researcher noted in 2007 that '[given] the exceptional salience and policy relevance of this concept, it is surprising to see that over $77 \%$ of scholars in leading political science journals who focus on terrorism fail to define it, and many of the remaining $23 \%$ offer definitions of their own without paying due consideration to the implications of their conceptual choices. ${ }^{21}$ Why, given the importance of an agreed definition of terrorism and the serious inhibitions of a lack of one, is there such academic paucity on the issue? Silke suggests the following may be the case:

'that there seems to be something of a war-weariness among established researchers over the definitional quagmire. Everyone is by now very familiar with the huge difficulties faced by any attempt to achieve consensus, and, rather than continue to struggle for the nebulous goal of an agreed framework, researchers seem to have resigned themselves to accepting the current state of uncertainty and to allow everyone to work within their own more limited frameworks. ${ }^{22}$

He goes on to argue that 'the lack of conceptual/definitional agreement is having some damaging impact' and that the field has become 'extremely applied':

'This can be seen not only in the very small number of writers and articles which tackle conceptual issues full-on, but also in other respects. For example, the field is almost entirely focused on issues of immediate, real-world relevance. The papers are about terrorist groups which are currently active, about current or imminent threats, or are focused on regions with recent or current experience of terrorist violence. There is virtually no effort to set terrorism within a broader context. .... this wider context is almost entirely ignored as terrorism research is driven by a need to provide a shortterm, immediate assessment of current groups and threats. Efforts to establish coherent and stable guiding principles have been almost entirely side-lined. This is a

\footnotetext{
${ }^{18}$ Silke, A., 'An Introduction to Terrorism Research', in Silke, A., (ed.), Research on Terrorism, Trends, Achievements and Failures, Frank Cass, London, 2004, p. 4.

${ }^{19}$ Silke, A., 'The Road Less Travelled: Recent Trends in Terrorism Research', in Silke, A., (ed.), Research on Terrorism, Trends, Achievements and Failures, Frank Cass, London, 2004, p. 207.

${ }^{20}$ Ranstorp, M., 'Mapping terrorism studies after 9/11', in Jackson, R., Breen Smyth, M., and Gunning, J., Critical Terrorism Studies, Routledge, 2009, p. 23.

${ }^{21}$ Bogatyrenko, O., 'Definitional Analysis of Terrorism: Constructing Concepts and Populations for Social Science Research', paper prepared for 2007 meeting of the International Studies Association, February-March 2007, p. 2, cited in Schmid, A., (ed.), The Routledge Handbook of Terrorism Research, Routledge, London and New York, 2011, p. 90.

${ }^{22}$ Op. cit. Silke, A., 'The Road Less Travelled: Recent Trends in Terrorism Research', p. 208 (note 19).
} 
serious cause for concern and is an issue which the more committed researchers will hopefully turn increased attention towards. ${ }^{23}$

'Stable and guiding principles' and the quest for greater conceptual development have therefore been at the mercy of the immediate concerns and sometimes knee-jerk reactions of policymakers (and often, therefore, of academics) to the latest terrorist atrocity. There is a real need for a commitment to the conceptual development of terrorism - so that any ultimate conceptualization of terrorism is sustainable, and is able to withstand the constant buffeting of the exigencies of the day and of research efforts rather narrowly being 'driven very much by issues of contemporary relevance' of concern to 'western democracies' and the USA. ${ }^{24}$ For example, a definition of terrorism should not simply be moulded by whatever the adversary of the day is doing - by, for instance, automatically including whatever the latest mode of activity that Al Qaeda is engaged with. Schmid, for instance, refers to the 'faulty circular reasoning' behind the view that 'once a group has been designated 'terrorist', all acts of violence by members of that group are 'terrorist'" ${ }^{25}$ Rather, acts of violence should be measured and assessed against a set of criteria that have been carefully considered and established to determine whether or not acts of violence constitute terrorism.

Linked to the notion of the use of 'terrorism' as a delegitimising tool by those in power is a third reason for focusing on the definition of terrorism. The emergence of critical perspectives within terrorism studies (often referred to as Critical Terrorism Studies or CTS) have posed questions as to how terrorism has 'traditionally' been studied and also, by implication, how it has been defined. There are, of course, many interpretations as to what it means to be 'critical'26, though in general this author prefers to see 'being critical' as a practice rather than signifying membership of one or other particular genre or school of thought. It is presumably a practice that all serious terrorism scholars engage in (and in this sense one should caution against the exclusive [mis]appropriation of the word 'critical' to a particular body of scholars). That said, some important perspectives have emerged from 'Critical Terrorism Studies' that need to be considered in any discussion on the definition of terrorism - not least that so-called 'orthodox' or 'traditional' terrorism studies has tended to exclude the state (especially democratic states) as potential perpetrators in definitions of terrorism. ${ }^{27}$

A fourth important reason for re-focusing on the definitional debate (and one that is not always acknowledged) is that any serious undertaking to theorise 'what terrorism is' is also inherently an endeavour to understand the phenomenon. As English has argued, any explanation and understanding of terrorism 'can be developed only if we clearly, credibly,

\footnotetext{
${ }^{23}$ Ibid. p. 208-9.

${ }^{24}$ Ibid. p. 210.

${ }^{25}$ Op. cit. Schmid, A., (ed.), The Routledge Handbook of Terrorism Research, p. 64 (note 6).

${ }^{26}$ See, for example, Gunning, J., 'Babies and bathwaters: reflecting on the pitfalls of critical terrorism studies', European Political Science, Palgrave Macmillan, Volume 6, No. 3, September 2007, p. 238.

${ }^{27}$ Although the acknowledgement that states have been by far the worst perpetrators of 'terror' is certainly not new, and nor is the particular focus within CTS on democratic states as culpable.
} 
plausibly, and honestly define the phenomenon that we actually face. ${ }^{28}$ This article, for example, aims to generate an understanding of terrorism as a particular method of violence rather than defined as something that is peculiar or inherent to particular types of perpetrator, ideology or cause. There are a wide range of actors that have used the method of terrorism whether they be terrorist groups or networks, states, guerrilla groups, extreme fringes of social movements and so on. In other words if we are scrutinising the activities of just terrorist organisations we are only considering part of the terrorism picture. Similarly, acts of terrorism have been carried out in the name of a variety of different causes or ideologies, most of them not inherently violent (or, more specifically, not terrorist).

A fifth related reason is that it has been argued by the author elsewhere that the concept of 'radicalization', it turns out, has not been a particularly useful one upon which to base a counter-terrorist strategy. ${ }^{29}$ It has not been clear as to who the radicalized are and responses in the UK in recent years have at times confusingly oscillated between tackling 'violent extremism' in particular to promoting 'shared values'. Indeed, the contention here is that the concept of 'radicalization' should be dropped and that the focus should return to what people do rather than the way they think - in other words there needs to be a refocus on (the method of) terrorism and not on more opaque notions of radicalization or on non-violent (but 'extremist') ideologies. ${ }^{30}$ Having been critical of the fact that there has been little consensus as to what is meant by radicalization it seems therefore natural that calls for a refocus on terrorism should also come with a commitment to revisiting the definition of the term and to reassessing its own conceptual dilemmas, for, like radicalization, it is very difficult to respond to something if one cannot agree on what that something is.

\section{The difficulty in defining terrorism}

Yet, defining terrorism is no easy task. Indeed, for some academics, it is an endeavour that is hardly worthy of serious contemplation as any attempt to secure agreement on a definition has thus far proved to be a fruitless exercise. The view is that any such aspiration will continue to disappoint and is therefore not worth the effort. Walter Laqueur wrote that, although 'terrorism is an unmistakeable phenomenon ... the search for a scientific, allcomprehensive definition is a futile enterprise ${ }^{31}$, while Edward Said remarked:

'The use of the word terrorism is usually unfocused, it usually has all kinds of implicit validations of one's own brand of violence, it's highly selective. If you accept this

\footnotetext{
${ }^{28}$ Op. cit. English, R., p. ix (note 4)

${ }^{29}$ Richards, A., 'The problem with 'radicalization', the remit of 'Prevent', and the need to refocus on terrorism in the UK', International Affairs, (January, 2011).

${ }^{30}$ See 'Contest: The United Kingdom's Strategy for Countering Terrorism', July 2011, available at: http://www.homeoffice.gov.uk/publications/counter-terrorism/counter-terrorism-strategy/strategycontest?view=Binary,$\left(\right.$ accessed November $\left.6^{\text {th }} 2013\right)$; and 'Prevent Strategy', June 2011, available at: http://www.homeoffice.gov.uk/publications/counter-terrorism/prevent/prevent-strategy/prevent-strategyreview? view=Binary (accessed November $6^{\text {th }} 2013$ ).

${ }^{31}$ Walter Laqueur, No End to War, Terrorism in the Twenty-First Century, Continuum International, 2004, p.238.
} 
norm, then it becomes so universally applicable that it loses any force whatsoever. I think it is best to drop it. ${ }^{32}$

Another argued that 'a definition of terrorism is hopeless ... terrorism is just violence that you don't like ${ }^{, 33}$ while Silke cautioned that the field is 'bogged down in conceptual mire' and that answers to what appear to be fairly basic questions (such as what is terrorism and what makes an act a terrorist act?) continue to be elusive. ${ }^{34}$ He summed up the general fatigue over the issue:

'For some, the definition debate is a hugely wasteful quagmire, undeserving of the energy it has swallowed over the years. Many experienced commentators hold such opinions. Weary of the heated and largely fruitless debates of the 1970s and 1980s, they view the necessity of a shared definition with a jaundiced eye, and consider the research effort expended on such efforts would be better applied to other more amenable issues. ${ }^{35}$

From a policymaking perspective, senior figures also found the challenge of defining terrorism daunting. Lord Lloyd of Berwick, in his review of terrorism legislation in the United Kingdom in 1996, conceded that 'there are great difficulties in finding a satisfactory definition. Indeed, I was unable to do so and I suspect that none of us will succeed. ${ }^{36}$ Lord Carlile, reviewer of counter-terrorism legislation in the UK from September 2001 to 2011 conceded that ' $[\mathrm{h}]$ ard as I have striven, and as many definitions as I have read, I have failed to conclude that there is one that I could regard as the paradigm. Unsurprisingly, I have been unable to achieve what was not achieved by Lord Lloyd - perhaps because it is not possible to do so. ${ }^{37}$ Yet, as Golder and Williams noted above, and as a European Commission Sixth Framework Programme Project on defining terrorism also remarked, there is from a legal perspective a need for precision and certainty. ${ }^{38}$

Laqueur, however, cautions those engaged in such a conceptual pursuit arguing that 'terrorism is dangerous ground for simplificateurs and generalisateurs' ${ }^{39}$ while others have proclaimed that 'it is unlikely that any definition will ever be generally agreed upon'

\footnotetext{
${ }^{32}$ Edward Said, cited in 'Environmental Terrorism: A Critique' by Shannon O'Lear in Stanley D. Brunn (ed.), 11 September and its Aftermath, Frank Cass, 2004, p. 132.

${ }^{33}$ R. E. Rubenstein, cited in op. cit. Schmid, A., 'Terrorism - The Definitional Problem', p. 397 (note 1).

${ }^{34}$ Silke, A., 'The Devil You Know: Continuing Problems with Research on Terrorism', Terrorism and Political Violence, Volume 13, No. 4, 2001, p.2.

${ }^{35}$ Op. cit. Silke, A., 'An Introduction to Terrorism Research' p. 3 (note 18).

${ }^{36}$ Lord Lloyd of Berwick, cited in Carlile, A., The Definition of Terrorism, March 15th 2007, p. 4, available at: http://www.official-documents.gov.uk/document/cm70/7052/7052.pdf (accessed November 6th 2013).

${ }^{37}$ Carlile, A., The Definition of Terrorism, March 15th 2007, p.4, available at: http://www.officialdocuments.gov.uk/document/cm70/7052/7052.pdf (accessed November 6th 2013).

${ }^{38}$ Op. cit. European Commission Sixth Framework Programme Project, 'Defining Terrorism' (note 1).

${ }^{39}$ Laqueur, W., quoted in op. cit. Schmid, A., 'Terrorism - The Definitional Problem', p. 378 (note 1).
} 
(authors' italics) ${ }^{40}$, and another has written of the 'The Indefinable Concept of Terrorism'. ${ }^{41}$ In 1986, Levitt summed up the challenge for those who set out to achieve the seemingly impossible:

'The search for a legal definition of terrorism in some ways resembles the quest for the Holy Grail: periodically, eager souls set out, full of purpose, energy and selfconfidence, to succeed where so many others before have tried and failed. Some, daunted by the difficulties and dangers along the way, give up, often declaring the quest meaningless. Others return claiming victory, proudly bearing an object they insist is the real thing but which to everyone else looks more like the same old used cup, perhaps re-decorated in a slightly original way. Still others, soberly assessing the risks, costs and benefits attendant upon the attempt, never set out at all, preferring to devote their energies to humbler but possibly more practical tasks. But the long record of frustrations and failures often seems to spur further efforts; the 99th [United Nations] Congress, for example, saw a dozen bills containing various attempts at legislative definitions of terrorism. ${ }^{42}$

Defining terrorism has thus been a controversial endeavour that has perplexed both academics and policymakers. The political, subjective and perjorative use of the term has rendered any prospect of achieving a universally agreed definition as remote indeed, and, as such, continued deliberation over the meaning of terrorism is often seen as a stale and redundant exercise.

This may especially be the case when one has to acknowledge that terrorism, like any social science concept, is ultimately a social construction and so there is, one has to concede, something of a paradox in trying to be definitive about it. As an 'ontologically unstable' term terrorism, therefore, hardly represents a 'brute fact' ${ }^{43}$ Its social construction means that in theory terrorism can indeed be whatever one says it is and that it therefore comes down to who has the power to define or who 'is heard the loudest'. It is also therefore the case that those who claim that the term has been abused are by definition themselves culpable of making some sort of knowledge claim as to what terrorism is and what it is not.

Such is the dilemma with all social science concepts - all of which have been socially constructed and whose meanings and applications have changed over time. But does this mean that, because we cannot speak 'truth' in defining these concepts, that we should abandon attempts to capture their meaning in historical and contemporary contexts? The answer is surely a resounding 'no' because not only do the meanings attributed to such

\footnotetext{
${ }^{40}$ Shafritz et al, cited in Silke, A., 'Terrorism and the Blind Men's Elephant', Terrorism and Political Violence, Volume 8, No. 3, 1996, p. 13.

${ }^{41}$ Fletcher, G., 'The Indefinable Concept of Terrorism', Journal of International Criminal Justice, Volume 4, No. 5 (2006).

${ }^{42}$ Levitt, G., 'Is Terrorism Worth Defining?', Ohio Northern University Law Review, Volume 13 (1986), No. 1, p. 97.

${ }^{43}$ Jackson, R., Jarvis, L., Gunning, J., and Breen Smyth, M., Terrorism, A Critical Introduction, Palgrave Macmillan, 2011, p. 119.
} 
concepts, like terrorism, often have major 'real-life' consequences but every academic discipline requires a degree of conceptual clarity to guide research. Otherwise, Wight has cautioned, terrorism research 'will always tend to drift into a form of journalistic speculation'. ${ }^{44}$ Moreover, as English has noted, 'the fact is that this word is simply not going to disappear from the political vocabulary (it is far too useful to too many people for this to occur), and so we should probably retain our commitment to establishing precise, coherent definitions of the word, rather than merely jettisoning it, ${ }^{, 45}$ and, as Schmid argues, 'giving up on the scholarly debate would leave the field to those who simply hold that ' $[\mathrm{t}]$ errorism is what the bad guys do' (B.M. Jenkins), or 'one man's terrorist is the other man's freedom fighter". ${ }^{46}$

Moreover, while 'terrorism' may be socially constructed, this does not mean to say that there cannot be a universally agreed definition of the concept, even if we acknowledge that such a definition would not be the 'truth' but the culmination of an agreed understanding at a given time in a contemporary context. In the academic literature of the past four decades a general consensus does appear to have developed as to what the core essence of terrorism is (and it is one that this author concurs with) - that terrorism entails the intent to generate a wider psychological impact beyond the immediate victims. While such a consensus may not amount to being the 'truth', the endeavour here is to generate an understanding and conceptualization of terrorism around this indispensable psychological dimension.

Simply abandoning terrorism as incapable of having any meaningful analytical value is therefore hardly tenable, and indeed would be an abdication of academic responsibility, not just because it would leave terrorism studies without a sufficient conceptual and theoretical foundation but because it would leave policymakers bereft of academic input to inform their own endeavours in defining the term. This is not, the author hastens to add, to be in 'service to power' but, as much as anything else, is to prevent the abuse of power.

\section{Prospects for defining terrorism?}

Having argued above for the need to enhance the analytical utility of the term 'terrorism', one may, however, have to concede the possibility that, in the course of our scrutiny, there might in fact be nothing qualitatively distinctive about terrorism, that from time immemorial it has been nothing more than a superficial and derogatory label - a delegitimising rhetorical device for violence that is in fact no different in essence to other forms of political violence. Some have suggested that the term 'terrorism' emerged (along with democratic systems of government) as a delegitimizing tool to describe the violence of those who threatened the status quo. Michael Blain, for example, has argued that ' $[t]$ he emergence of terrorism as a concept and political problem was associated with the development of modern liberal democracies' and, using Michel Foucault's notion of subjection, stated that '[ $\mathrm{t}]$ he invention

\footnotetext{
${ }^{44}$ Wight, C., 'Theorising Terrorism: The State, Structure and History', International Relations, 2009, 23, p.105.

${ }^{45}$ Op. cit. English, R., p.21 (note 4).

${ }^{46}$ Op. cit. Schmid, A., (ed.), The Routledge Handbook of Terrorism Research, p. 42 (note 6).
} 
of a discourse of terrorism was a strategic response to danger, and could be deployed through basic regulatory practices of subjection. ${ }^{47}$ This ties in with contemporary 'critical' approaches that argue that 'the accepted knowledge of the field ... functions ideologically to reinforce and reify existing structures of power within society, particularly that of the state' ${ }^{48}$

Seen in this way, if the term 'terrorism' was simply forged as a means of practicing subjection in order to reinforce and perpetuate prevailing power structures, then one might indeed argue that its perjorative nature is 'in its genes', that 'moral opprobrium' 49 is ineluctably intrinsic to the concept. If the discourse of 'terrorism' was generated to serve this purpose then how can one confound centuries of perjorative use from its inception and pretend that we can redeem some kind of analytical quality that it has never had? Is terrorism therefore, after all, violence that we simply 'do not like' or whose cause we disagree with? If it was invented as a perjorative term ${ }^{50}$ simply to discredit the violence of adversaries (violence which was not actually qualitatively distinctive from other forms of violence) then one could indeed argue that prospects for endowing terrorism with some sort of analytical quality are limited.

It is this line of thinking that underpins and helps to sustain the 'one person's freedom fighter is another's terrorist' mantra for the same 'practice of subjection' takes place here: that there is nothing intrinsically different about terrorism, that it is merely the violence perpetrated by those we disagree with, that it is simply violence that is illegal or seen as illegitimate by the prevailing power holders. Wight reminds us that ' $[t]$ he history of the development of the modern state can be understood as a long process of appropriation and accumulation (of territory, peoples and resources) achieved through the use of violence, a process that had winners and losers. ${ }^{51} \mathrm{He}$ therefore sees the phenomenon of terrorism as inextricably bound up with the development of the state. It would indeed be strange, then, if both 'winners and losers' endorsed the status quo (and its related contemporary territorial and political configurations) at any given time. Naturally enough those winning the game, precisely because they are winning, have decided that the game has ended and have sought to consolidate the status quo. In this sense terrorism (at least of the 'powerless' or 'power seekers') can be viewed as a natural part of the 'system' as one of a number of opposing political activities, and not qualitatively different to other forms of political violence. ${ }^{52}$ The first possibility we have to consider, therefore, is that there is actually nothing qualitatively distinctive about terrorism compared with other forms of political violence.

\footnotetext{
${ }^{47}$ Blain, M., 'On the Genealogy of Terrorism', in Staines, D., (ed.), Interrogating the War on Terror: Interdisciplinary Perspectives, Cambridge Scholars Publishing, Newcastle (UK), 2007, pp. 50-51.

${ }^{48}$ Jackson, R., 'Knowledge, power and politics in the study of political terrorism', in Jackson, R., Breen Smyth, M., and Gunning, J., (eds.), Critical Terrorism Studies, Routledge, 2009, p. 67.

${ }^{49}$ Op. cit. Gearty, C., Terror, p. 6 (note 3).

${ }^{50}$ This is notwithstanding those rare examples of those who have described themselves as 'terrorist'. (See Hoffman, B., Inside Terrorism, Columbia University Press, 1998, p. 29).

${ }^{51}$ Op. cit. Wight, C., 'Theorising Terrorism: The State, Structure and History', p. 101 (note 44).

52 The notion that 'terrorism' is merely a delegitimising tool used to discredit oppositional political violence, however, does not explain why more 'positive' labels are used for some forms of this violence (such as guerrilla warfare). A common distinction made is that terrorism targets civilians whereas guerrilla warfare does not (although, of course, guerrilla organisations have used the method of terrorism).
} 
If we try and take a step further than this in theorising what terrorism is (beyond merely being a derogatory label) a second possibility is that it can perhaps be categorised as simply a lower level of political violence. Terrorism can thus be seen as simply at the lower end of the scale or, as many have suggested, as 'the weapon of the weak' (though one could argue that terrorism is not just carried out by the weak). This perspective again does not view terrorism as qualitatively different to other forms and so, as with the first perspective above, it would leave us with little to theorise about in relation to any distinctiveness about terrorism.

Notwithstanding these two perspectives (terrorism as merely a label and/or a lower level of political violence), the author will endeavour to argue for a third possibility - that there is something distinctive about terrorism that is worth theorising about, that it is wholly unsatisfactory, for example, to simply define or describe terrorism as 'you know it when you see it' or, equally vaguely, that '[w]hat looks, smells and kills like terrorism is terrorism'. ${ }^{53}$ Schmid and Longman, in their seminal contribution, argued that:

'... even a "minimum of theory" requires some consensus about what to theorize about ...The search for a universalist definition of terrorism is one which scientists cannot give up. Without some solution to the definitional problem ... there can be no uniform data collection and no responsible theory building on terrorism. ${ }^{54}$

For many, it may seem obvious what is distinctive about terrorism - that it is a form of 'extranormal' violence that targets civilians in a peacetime environment. Indeed, confronted with attacks like those of 9/11 and 7/7, 'societies are clear that terrorism is an especially violent and unethical wrong. ${ }^{55}$ Terrorists have deliberately targeted civilians in peacetime environments and it is this that makes terrorism so shocking and extranormal. As Laqueur once wrote, a characteristic feature of terrorism is 'the violation of established norms. ${ }^{56}$

Yet, states have themselves, of course, also targeted civilians, although in the context of war these are now called 'war crimes'. From an International Humanitarian Law perspective Koechler proposed 'a comprehensive or unified approach' to attacks on civilians both in peace and war time:

'In a universal and at the same time unified system of norms - ideally to be created as an extension of existing legal instruments -, there should be corresponding sets of rules (a) penalizing deliberate attacks on civilians or civilian infrastructure in wartime (as covered by the Geneva Conventions), and (b) penalizing deliberate attacks on civilians in peacetime (covered by the 12 so far anti-terrorist conventions). ${ }^{, 57}$

\footnotetext{
53 Jeremy Greenstock, (former) British Ambassador to the United Nations, in op. cit. Schmid, A., 'Terrorism The Definitional Problem', p. 375 (note 1).

${ }^{54}$ Schmid, A., and Longman, A., Political Terrorism, Transaction Books, Third Edition, 2008, p. 3.

${ }^{55}$ Gearty, C. (ed.), Terrorism, Dartmouth Publishing, 1996, p. xi.

${ }^{56}$ Laqueur, W., Terrorism, Weidenfeld and Nicholson, London, 1977, p. 3.

${ }^{57}$ Koechler, H., cited in Santos, S., 'Terrorism: Toward a Legal Definition', The Manila Times, October $5^{\text {th }}$ 2002, available at: http://www.i-p-o.org/Manila-Times1.htm (accessed November 6th 2013).
} 
One inclination then has been to conceptualize terrorism within the context of the broader framework of international norms to do with the protection of the 'innocent', 'civilians' or 'non-combatants' and hence the proposal that terrorism be viewed as the peacetime equivalent of a war-crime. States are obliged to comply with these norms and where they haven't they suffer the indignation of the international community. In other words there is generally a compliance, or at least a pretence of compliance, with these norms of international behaviour whereas those carrying out acts of terrorism deliberately flout them, and that this is what makes terrorism different. From a policymaking perspective, it is understandable, and perhaps even logical, that the application of these norms across the board should inform a definition of terrorism - that what marks acts of political violence out as terrorism is the deliberate targeting of civilians or non-combatants.

Yet, as the author will go on to argue, anybody can be a victim of terrorism and this includes non-civilians and combatants. While civilian or non-combatant targeting may be a frequent or even predominant feature of terrorism it is not definitional of the concept, and a general definition of terrorism must apply to all cases. What, then, is peculiar to all cases of terrorism and how can this be captured in a definition?

\section{The Essence of Terrorism}

Before proposing three key assumptions when approaching the definition of terrorism it is worth reiterating what the author views as indispensable to the phenomenon: that the essence of terrorism lies in the intent or purpose behind the act of violence rather than in the act itself, namely to generate a wider psychological impact beyond the immediate victims. The definition of terrorism ultimately proposed here is therefore a purpose-based one. ${ }^{58}$ The idea that the intent or the purpose behind the act lies at the heart of terrorism is captured in Schmid's observation:

'There is, in our view, a solid conceptual core to terrorism, differentiating from ordinary violence. It consists in the calculated production of a state of extreme fear of injury and death and, secondarily, the exploitation of this emotional reaction to manipulate behaviour. ${ }^{59}$

What is therefore key to a definition of terrorism is that the intent behind the act of violence, or the threatened act of violence, 'is psychological and symbolic, not material' ${ }^{60}$ Hoffman also argued that terrorism entails:

'the deliberate creation and exploitation of fear through violence or the threat of violence in the pursuit of political change .... Terrorism is specifically designed to have far-reaching psychological effects beyond the immediate victim(s) or object of

\footnotetext{
${ }^{58}$ See op. cit. Schmid, A., and Longman, A., p. 50 for purpose-based typologies of terrorism (note 54).

${ }^{59}$ Ibid. pp. 20-21.

${ }^{60}$ An 'American critic' cited in op. cit. Schmid, A., and Longman, A., Political Terrorism, p. 8 (note 54).
} 
the terrorist attack. It is meant to instil fear within, and thereby intimidate, a wider "target audience" that might include a rival ethnic or religious group, an entire country, a national government or political party, or public opinion in general. ${ }^{61}$

Central to terrorism, therefore, is the ' 'organized and systematic attempt to create fear'... that aims at attaining specific political ends (motivation) through the creation of fear, and not through the mere act of violence. ${ }^{, 62}$ As Jenkins also argued: '[f]ear is the intended effect, not the byproduct, of terrorism. ${ }^{63}$ Terrorism is therefore primarily concerned with generating a psychological impact over and above any tangible or military gain. ${ }^{64}$ It is this intent behind the act of violence that determines whether or not it is an act of terrorism. According to Gearty '[a] pure terrorist act results in everyone recoiling in horror, with the words 'it could have been me' etched on their mind' ${ }^{65}$

\section{Three preliminary assumptions when approaching the definition of terrorism}

\section{1) There is no such thing as an act of violence that is in and of itself inherently terrorist.}

Terrorism's physical manifestation can vary from the use of incendiary devices, to gun attacks, to a variety of different types of bomb attacks (including suicide bomb attacks), to 'mass casualty' attacks on the scale of 9/11 and so on. Therefore the physical part of terrorism can be seen as consisting of a range of different methods. The World Incidents Tracking System, for example, codes 'terrorist incidents' as the following: 'armed attack, arson/firebombing, assassination, assault, barricade/hostage, bombing, CBRN, crime, firebombing, hijacking, hoax, kidnapping, near miss/non-attack, other, theft, unknown, and vandalism. ${ }^{, 66}$

None of these acts of violence, however, even those that might be commonly associated with terrorism (such as bombings and hijackings), are in and of themselves inherently terrorist acts. It is only when one adds layers of meaning to the physical act that one can then determine whether or not such an act can be labelled terrorism. For example, a shooting can be an act of crime, terrorism or warfare. But once layers of meaning have been endowed upon the act then we can broadly refer to the method of terrorism as distinct from the different

\footnotetext{
${ }^{61}$ Hoffman, B., Inside Terrorism, Columbia University Press, 1998, pp. 43-4.

${ }^{62}$ European Commission Sixth Framework Programme Project, 'Defining Terrorism', p. 57 (note 1).

63 Jenkins, B., cited in op. cit. Schmid, A., and Longman, A., Political Terrorism, p. 36 (note 54).

${ }^{64}$ A distinction should be made, however, between the purpose of a specific act and the broader political goal or motive. The former may be successfully achieved but the latter may not (in fact very rarely is).

${ }^{65}$ Op. cit. Gearty, C., Terror, p. 9 (note 3). Although, as argued above, the victims or the 'target group' of terrorism should not by definition be restricted to civilians or non-combatants, such targets can no doubt elicit a more shocking and greater psychological impact.

${ }^{66}$ See 'National Counterterrorism Center: Annex of Statistical Information', US Department of State, available at: http://www.state.gov/j/ct/rls/crt/2008/122452.htm (accessed November 6th 2013).
} 
methods or manifestations of the violence itself. These layers of meaning render terrorism as not just being about violence or the threat of violence and is why any definition that focuses on the particular acts of violence themselves as integral to terrorism misses the point when it comes to establishing the meaning of the concept.

The use of examples might help to illustrate the point. A suicide bomb self-detonated in a crowded market place might inescapably be labelled an act of terrorism without any further thought - that it 'looks' and 'smells' like terrorism. ${ }^{67}$ In theory, however, such an act is still possible without a political motive, thus rendering the act as something other than terrorism. Hypothetically, a disgruntled individual may have carried out the act in revenge against their work place (or former work place) or even against a local community.

A car bomb might also be ineluctably associated with terrorism. One exploded in Kent in the United Kingdom in March 2010 and a pregnant woman was badly injured. The incident may have looked like an act of terrorism - a very similar act, for example, to the car bombs that the IRA commonly used to generate a psychological impact and to draw attention to its political cause. The difference is that the Kent car bomb was planted by the victim's husband who was said to be suffering from post-traumatic stress. In other words, even an act of violence that may be commonly seen as synonymous with terrorism (the car bomb) is not necessarily an act of terrorism unless it is imbued with meaning (ie. a political motive and designed to have a psychological impact beyond the immediate victim[s]).

Acts of terrorism may entail shooting attacks, perhaps best exemplified by the Al Shabaab attack in Nairobi in September 2013, or the November 2008 attack in Mumbai, or by Irish Republican sniper attacks. Again, not all cases of shootings in civilian environments are terrorist. Although Raoul Moat 'terrorised' his community in July 2010 in Northumberland in the UK after going on the run, his shootings were not acts of terrorism because they lacked a political goal. The same can be said of the actions of a sacked police officer, Rolando Mendoza, in Manila in the Philippines who seized control of a bus and demanded to be reinstated (with a subsequent death toll of eight after a shoot-out with the authorities). In other words it is wholly inadequate to describe terrorism as 'you know it when you see it' or ' $[\mathrm{w}]$ hat looks, smells and kills like terrorism is terrorism'. ${ }^{68}$

What about the archetypal acts of terrorism of recent times - how, for example, can one not immediately recognise the attacks of $9 / 11$ as acts of terrorism? Again, taken in isolation, each act of violence on 9/11 might not have been an act of terrorism. Any such act might have been carried out by a psychologically disturbed individual, or by those seeking a ransom where crew and passenger resistance may have led to an aircraft crashing, or, considered in isolation, the first crash could have been a tragic accident. Indeed, after this first incident it was by no means clear at that stage that we were witnessing an act of terrorism. In the case of the London bombings of 2007 there were some early indications that an electrical fault might have been the cause. The point is that even in cases of what might subsequently be called

\footnotetext{
${ }^{67}$ Jeremy Greenstock, (former) British Ambassador to the United Nations, in op. cit. Schmid, A., 'Terrorism The Definitional Problem', p. 375 (note 1).

${ }^{68}$ Ibid.
} 
archetypal acts of terrorism conclusions as to whether they could be classified as acts of terrorism could not be made immediately. Of course, once layers of meaning were added then it could be confirmed that these were indeed acts of terrorism - that these were deliberate and simultaneous attacks, that they were politically motivated, and that they aimed to generate a massive psychological impact amongst a much broader group than the victims.

So, in summary, the first assumption proposed that informs our discussion as to what terrorism is, is that there is no such thing as an act of violence that can in and of itself inherently be described as an act of terrorism. Whatever the type of violence chosen 'the primary intent [of terrorism] ... is to produce fear and alarm that may serve a variety of purposes' ${ }^{69}$ The essence of terrorism lies in the intent behind the act of violence, and the 'primary intent' of terrorism is to spread fear beyond the immediate victims. If it is not intended to have this wider psychological impact then it is not terrorism.

\section{Implication}

The implication of this first assumption is that any lists of terrorist 'acts' or of the physical manifestations of terrorism do not bring us any closer to capturing what terrorism is. Any conjecture, therefore, as to which of the wide range of types of violent acts should constitute terrorism is unnecessary. For example, Weinberg et al need not have concerned themselves with this when they argued that 'unless we are willing to label as terrorism a very wide range of violent activities, we may be better off finding another governing concept or looking elsewhere for a definition ${ }^{70}$ - for it is the purpose of, and intent behind, the act of violence (and not the type of act itself) that is integral to the phenomenon and determines whether or not it can be regarded as an act of terrorism.

One could also suggest, therefore, that the United Nations approach of countering certain acts as 'terrorist acts' does not assist us in conceptualizing terrorism (though defining terrorism was not its primary intention when drafting its Conventions). Nor do such references as 'Hijacking may be described as a special type of terrorism' ${ }^{\text {'1 }}$ - this is because there can, as in the case of other forms of 'terrorist' violence, be non-terrorist hijackings. ${ }^{72}$

When focusing on a definition of terrorism, any list of types of violence that are labelled 'terrorist acts' are not then going to be particularly useful in helping us to conceptualize terrorism or in grasping what the essence of terrorism is. As such, the UN and the EU's approach of identifying and addressing 'a wide spectrum of terrorist acts', or French law that

\footnotetext{
69 Jenkins, B., 'The Study of Terrorism: Definitional Problems', the RAND Corporation, December 1980, p. 2 , available at: http://www.rand.org/pubs/papers/2006/P6563.pdf (accessed November 6th 2013).

${ }^{70}$ Leonard Weinberg, Ami Pedahzur, and Sivan Hirsch-Hoefler, 'The Challenges of Conceptualizing

Terrorism', Terrorism and Political Violence, Volume 16, Winter 2004, No. 4, p. 787.

${ }^{71}$ Dugard, J., 'International Terrorism: Problems of Definition', International Affairs, Volume 50, No. 1, January 1974, p. 71.

${ }^{72}$ For example, in theory, hijackings can be carried out for non-political reasons, such as for ransom demands.
} 
specifically names and describes the acts that constitute terrorism ${ }^{73}$, or indeed any such lists $^{74}$, while from a legal perspective may be useful, again serve only to deviate us from this, because terrorism is not inherent to any particular act or type of violence. This perhaps comes as something of a relief because it means that, in the course of our conceptual deliberations, we do not then have to address the emergence of new and different types of acts of violence that may develop along with advances in technology. As Tiefenberg observes, 'as new forms of technology are created, new forms of terrorist acts are likely to develop' though his suggestion (from a legal perspective) that 'this problem might be countered by enacting an extensive list of specific crimes of terrorism' would again not bring us any closer to capturing what terrorism is. ${ }^{75} 76$

\section{2) Terrorism is a particular method used by a wide variety of actors and so perpetrator or cause based definitions (beyond political motive) are unhelpful}

The notion of terrorism as a method is certainly not new - in fact it was 'formulated' as a 'method of combat' in the Encyclopaedia of the Social Sciences in $1936 .{ }^{77}$ When we refer to the 'method' of terrorism we are not then alluding to the various types of violence used (ie. the physical manifestation of terrorism), but to the purpose or intent behind the act of violence, which is to generate a psychological impact beyond the immediate victims. Terrorism, with this indispensable psychological dimension, is a particular method of violence that has been used by a wide variety of actors and requires more than just an act of violence or the threat of violence. A definition does not need to refer to the perpetrator or the cause (other than being political) but it does need to establish the intent behind that act of violence, namely to 'terrorise' (and/or to motivate/mobilise) a wider population.

\section{Implications}

\footnotetext{
73 Article 421-1 of the French Criminal Code lists the following acts as terrorist acts: 'Attempted murder, assault, kidnapping, hostage-taking on airplanes, ships, all means of transport, theft, extortion, destructions, and crimes committed during group combat, the production or ownership of weapons of destruction and explosives including the production, sale, import and export of explosives, the acquisition, ownership, transport of illegal explosive substances, the production, ownership, storage, or acquisition of biological or chemical weapons, and money laundering.' (cited in Tiefenbrun, S., 'A Semiotic Approach to a Legal Definition of Terrorism', ILSA Journal of International and Comparative Law, Vol. 9 (2003), No. 2, p. 71).

74 Bassiouni lists fourteen specific acts of terrorism which are: 'aggression, war crimes, crimes against humanity, genocide, apartheid, unlawful human experimentation; torture, slavery and slave-related practices; piracy, and unlawful acts against the safety of maritime navigation; kidnapping of diplomats and other internationally protected persons; taking civilian hostages; serious environmental damage; or serious violation of fundamental human rights.' (cited in op. cit. Tiefenbrun, S., 'A Semiotic Approach to a Legal Definition of Terrorism', p. 393, note 73).

${ }^{75}$ Op. cit. Tiefenbrun, S., ‘A Semiotic Approach to a Legal Definition of Terrorism', p. 69 (note 73).

${ }^{76}$ While it is not the particular act of violence itself that determines whether or not that act is terrorism, but the intent and purpose behind it, the seriousness of the act is, however, of relevance to the conceptual discussion. For example, an issue of contention is how serious an act of violence must be to be considered an act of terrorism.

${ }^{77}$ Op. cit. Schmid and Longman Schmid, A., and Longman, A., Political Terrorism, p. 13 (note 54).
} 
The utility of viewing terrorism as a method (or a tactic) is that it allows us to implicitly acknowledge that terrorism is not particular to any type of actor for it has been used by a wide variety of actors, not just terrorist organisations. An actor-free definition of terrorism means that no type of perpetrator of terrorism is excluded, be they states, social movements, guerrilla groups, terrorist groups and so on. In this context, a clearer distinction in terrorism studies 'between 'terrorist groups' and groups that deploy terrorism as one of many insurgent and political strategies' is a worthy one to make. ${ }^{78}$ As Weinberg rightly observed the notion that 'one man's terrorist is another man's freedom fighter' is confusing the goal with the activity. ${ }^{79}$ So too, therefore, does the view (apparently articulated by the UN SecretaryGeneral in March 1987 in relation to the PLO and SWAPO) that 'sometimes it is difficult to tell where terrorism ends and the struggle for self-determination begins. ${ }^{, 80}$

Schmid, in 1983, suggested that 'terrorism is a method of combat in which random or symbolic victims become targets of violence ...' and aptly makes no reference as to who carries out this 'method of combat' 81 , and Cooper rightly argues that we 'can no longer afford the fiction that one person's terrorist is another's freedom fighter. Fighting for freedom may well be his or her purpose, but if the mission is undertaken through the employment of terrorist means, a terrorist he or she must remain ${ }^{82}$. Crenshaw also makes the point that: "the identity of the actor [whether state or non-state] does not matter to the specification of the method'. ${ }^{83}$

It is also why many observers miss the point when they pose such questions as: "where to draw the line between the quest for nationalist identity and an act of terrorism ...?" ${ }^{84}$ or when Yasir Arafat declared that:

'The difference between the revolutionary and the terrorist ... lies in the reason for which each fights. For whoever stands by a just cause and fights for the freedom and liberation of his land from the invaders, the settlers and the colonialists, cannot possibly be called a terrorist ...., ${ }^{85}$

The difference between the terrorist and the non-terrorist does not lie in the reason for which one fights, as Arafat proclaimed. Otherwise we are conceding that terrorism really is

\footnotetext{
${ }^{78}$ Op. cit. Schmid, A., (ed.), The Routledge Handbook of Terrorism Research, p. 28 (note 6).

${ }^{79}$ Weinberg, Leonard, 2005. Global Terrorism, A Beginner's Guide, Oneworld, p. 2.

${ }^{80}$ Romanov, V., 'The United Nations and the Problem of Combatting International Terrorism', Terrorism and Political Violence', Terrorism and Political Violence, Volume 2, Autumn 1990, No. 3, p. 295.

${ }^{81}$ Schmid, A. (1983). Political Terrorism: A Research Guide to Concepts, Theories, Data Bases and Literature. New Brunswick: Transaction, p. 111.

${ }^{82}$ Cooper (2001, p. 887), cited in Griset, P., and Mahan, S., Terrorism in Perspective, Sage, Thousand Oaks (California) and London, 2003, p. 59, available at: http://books.google.co.uk/books?hl=en\&lr=\&id=YpmZ76zRW2oC\&oi=fnd\&pg=PR9\&dq=defining+terrorism \&ots $=\mathrm{mN6S1K} 4 \mathrm{htr} \& \operatorname{sig}=\mathrm{YT} 9 \mathrm{v} 2 \mathrm{D} 61 \mathrm{Mm} 8 \mathrm{eKpHI} \operatorname{cszBCfU} 9 \mathrm{mUM} \# \mathrm{v}=$ onepage $\& \mathrm{q}=$ defining\%20terrorism\&f=false (accessed November $6^{\text {th }} 2013$ ).

${ }^{83}$ Op. cit. Crenshaw, M., Explaining Terrorism, Causes, Processes and Consequences, p. 207 (note 8).

${ }^{84}$ Op. cit. Acharya, U., 'War on Terror or Terror Wars: The Problem in Defining Terrorism', p. 656 (note 13).

${ }^{85}$ Arafat, Y., cited in op. cit. Hoffman, B., Inside Terrorism, p. 26 (note 61).
} 
'violence that we don't like' (or whose cause we disagree with) and that there is in fact nothing qualitatively distinctive about terrorism compared with other forms of political violence. In the course of endeavours to define terrorism in the aftermath of the 1972 Munich Olympics attack by the Palestinian Black September group, Syria argued that 'the international community is under legal and moral obligation to promote the struggle for liberation and to resist any attempt to depict this struggle as synonymous with terrorism and illegitimate violence. ${ }^{86}$ Again, any attempt to either instinctively deny the use of terrorism because of the 'worthiness' of the cause, or indeed, conversely, to conflate terrorism with certain causes that one finds unpalatable, obfuscates endeavours to elevate terrorism as an analytical concept.

Yet, such associations (and non-associations) have proved remarkably (and unhelpfully) resilient. Pillar has also rightly argued that terrorism is something that 'people (or groups, or states) $d o$, rather than who they are or what they are trying to achieve' (author's italics) ${ }^{87}$. Terrorism, as a method, should be 'defined by the nature of the act, not by the identity of the perpetrators or the nature of their cause. ${ }^{, 88}$

There may be ideologies that have been interpreted, adapted or distorted to explicitly justify the use of terrorism and where terrorism may then become ideologically embedded. In this sense one might indeed call them 'terrorist ideologies' where the use of terrorism is intrinsic to the doctrine. It could be argued that this is the case with Al Qaeda and the notion of terrorism and political violence as a religious duty, or indeed with the tradition of 'physical force' Irish republicanism - for example Patrick Pearse's proclamations of the notion of selfsacrificial acts as being a compelling symbol of republican ideology. But there are, of course, many nationalist, religious, left wing, right wing, and single issue (anti-abortion, animal rights, environmental) ideologies that are not inherently violent though terrorism has often been employed in their name. When conceptualizing terrorism, therefore, there is no one doctrine, violent or otherwise, that can claim ownership of terrorism - it is a method of violence that has at some time or other been perpetrated in the cause of doctrines within all of these categories.

What this way of viewing terrorism enables us to do is to more accurately describe the actors that have often been labelled 'terrorist groups'. For example, the Revolutionary Armed Forces of Colombia (FARC) can more clearly be seen as a guerrilla group that has used terrorist tactics. Hamas can be seen as a social and political movement that has also used the method of terrorism. There have been those who claim to be acting on behalf of animal rights

\footnotetext{
${ }^{86}$ Cited in Hoffman. B., 'Defining Terrorism', in Howard, R. And Sawyer, R., (eds.), Terrorism and Counterterrorism, Understanding the New Security Environment, Readings and Interpretations, McGraw-Hill, 2002, p. 16.

${ }^{87}$ Pillar, P., 'The Dimensions of Terrorism and Counterterrorism', in op. cit. Howard, R. And Sawyer, R., (eds.), Terrorism and Counterterrorism, Understanding the New Security Environment, Readings and Interpretations, p. 28 (note 86).

${ }^{88}$ Op. cit. Jenkins, 'The Study of Terrorism: Definitional Problems', pp. 2-3 (note 69).
} 
that have on occasion used terrorist tactics, although one could argue that most of what animal rights 'extremists' do is not 'terroristic'. ${ }^{89}$

In fact, what becomes apparent is that it is rarely the case that there are what one might call 'pure' 'terrorist organisations'. Crenshaw concurs that it is very unusual for terrorism to be used exclusively as a form of struggle, citing the Abu Nidal as one of the few possible examples. ${ }^{90}$ The so-called Fighting Communist Organisations (FCOs) of the 1970s and 80s (such as the Red Army Faction, Direct Action, The Red Brigades and November 17) could arguably be seen as other instances. But in general terrorism forms but one part of the political activity of those who carry it out, and in some cases this other activity includes other forms of political violence. Guerrilla movements, such as FARC or the defeated Liberation Tigers of Tamil Eelam (LTTE), used traditional guerrilla tactics (such as attacking state forces in the open) as well as acts of terrorism. Crenshaw lists a number of what she calls 'internal wars' (post WW2) that have been 'accompanied by terrorism' including the 'Phillipines, Cyprus, Malaya, Palestine, Tunisia, Morocco, Algeria, Vietnam, [and] Latin America' ${ }^{91}$

\section{3) Acts of terrorism are not just carried out against civilians or non-combatants.}

A third assumption that the author makes when approaching the definition of terrorism is that, while acts of terrorism are very often (even predominantly) carried out indiscriminately or against civilian or non-combatant targets, civilian or non-combatant targeting should not be definitional of terrorism. ${ }^{92}$ Indeed, Narodnaya Volya, often cited as one of the most wellknown of terrorist antecedents, described its activity as 'the destruction of the most harmful persons in the government' (rather than civilians per se). ${ }^{93}$ Terrorism can entail violence against 'any person', as stated in the United Nations' draft comprehensive convention, despite the objections of those who argue for the centrality of civilian or non-combatant targets in the definition. ${ }^{94}$ In 1978 Crenshaw also argued that although the victims of terrorism are usually civilian 'they may include the military or the police' ${ }^{95}$

A brief survey of Easson and Schmid's 250 definitions of terrorism appears to endorse the view that terrorism is not just carried out against civilians or non-combatants. In fact, most of the definitions in their compilation do not make explicit reference to civilians or non-

\footnotetext{
${ }^{89}$ As argued by Schmid, A., (personal communication).

${ }^{90}$ Op. cit. Crenshaw, M., Explaining Terrorism, Causes, Processes and Consequences, p. 4 (note 8).

${ }^{91}$ Crenshaw, M., 'The concept of revolutionary terrorism', The Journal of Conflict Resolution (pre 1986), Volume 16, No. 3, September 1972, p. 395.

92 For a discussion on this see also Held, V., 'Terrorism and War', The Journal of Ethics, 8, 2004.

${ }^{93}$ Narodnaya Volya, cited in op. cit. Schmid, A., (ed.), The Routledge Handbook of Terrorism Research, p. 99 (note 6).

${ }^{94}$ See Op. cit. Schmid, A., (ed.), The Routledge Handbook of Terrorism Research, p. 55 (note 6).

${ }^{95}$ Crenshaw, M., quoted in op. cit. Schmid, A., (ed.), The Routledge Handbook of Terrorism Research, p. 118 (note 6).
} 
combatants as being victims (approximately 70 of the 250 make reference to 'civilian', 'noncombatant' or 'innocent' victims, with about half of these appearing in post-9/11 definitions). There are others that use more general terms, such as 'targeting a population' or a 'group', and there are a few that emphasise the arbritrariness and/or indiscriminate nature of terrorist acts. $^{96}$

Schmid argues that the 'very core of terrorism' is that ' $[\mathrm{t}]$ he direct victim of violence (or threat thereof) is different from the ultimate target (audience)', and that '[f]or this reason anyone can, in principle, become a victim of terrorism' (italics added). ${ }^{97}$ Yet, in the same piece Schmid conversely argued that:

'If those opposing terrorism want to maintain the moral high ground, they will have to observe this distinction between the unarmed civilian population and regular or irregular armed forces. However, they should only label as 'terrorism' attacks that deliberately target civilians and non-combatants. ${ }^{, 98}$

This narrower approach, as we have argued earlier, may, in keeping with international norms, be borne of a general desire to protect civilians and 'protected persons' from all forms of political conflict. Contrary to the purpose-based approach to the definition of terrorism proposed in this article, this represents a moral victim-based approach. If we agree, however, that the essence of terrorism lies in its primary intent to generate a psychological impact beyond the immediate victims then, based on this, terrorism can be carried out against both non-combatant and combatant targets. It is then another question as to which forms of terrorism (based on target differentiation) should be of more concern to policymakers than others. Were not, for example, many of the 'combatant' targets of the IRA victims of terrorism, providing the aim was to generate a psychological impact beyond the immediate casualties? Terrorism can be carried out against anyone, providing the victims or object of attack serve sufficiently as 'message generators' to a wider group or audience.

In arguing that acts of terrorism can take place against combatants in war, one might consider the example of the 'rogue' Afghan soldiers who have turned on NATO troops. If this is a concerted strategy of intimidation against the wider NATO troop body then these can certainly be classified as acts of terrorism. Yet, civilians were not targeted, nor, arguably, did they take place in a peacetime environment. Thus, acts of terrorism are possible within war providing the psychological impact is the primary objective over the physical one. ${ }^{99}$

\footnotetext{
${ }^{96}$ Op. cit. Schmid, A., (ed.), The Routledge Handbook of Terrorism Research (note 6).

${ }^{97}$ Ibid. p. 80. Though Schmid does suggest (p. 81) that the army could be a target audience and hence be a victim of terrorism in this sense, rather than being a direct victim.

${ }^{98}$ Ibid. p. 81.

${ }^{99}$ One of the challenges of arguing that anyone (including combatants) can be a victim of terrorism (providing wider psychological impact is the primary purpose) is that surely all acts of political violence (including acts of warfare) are intended to have some degree of psychological impact so what, therefore, is the difference between terrorism and, for example, conventional acts of warfare? This author would argue that for it to be terrorism psychological impact has to be the primary motivation whereas with war it tends to be physical/tangible gain through damage to an adversary's war effort or the acquisition/retention of territory. This then prompts us to consider a further challenge - what then is the difference between terrorism and psychological warfare? Here, I
} 
The case of the 'rogue shootings' or 'green on blue' attacks in Afghanistan merit closer scrutiny. While it has been argued that most of the attacks have 'nothing to do with the Taliban' and that they tend to be 'rooted in a mixture of personal arguments and cultural misunderstandings' at least some of the attacks have been linked to the Taliban. ${ }^{100}$ Indeed, the Nato Secretary-General argued that the Taliban "had "played out a strategy" to undermine confidence in the Afghan security forces'. ${ }^{101}$ It was widely reported that the green on blue attacks had a wider and negative impact on NATO troop morale - in other words the acts of violence have generated a wider psychological impact beyond the immediate victims. Hypothetically, if this psychological impact was the primary purpose of the attacks, then one could describe them as acts of terrorism. ${ }^{102}$

If the main purpose of the acts of violence carried out by the resistance movements of the second world war (in opposition to nazi rule) was to generate a psychological impact beyond the immediate victims then such acts could also be classified as acts of terrorism against military targets in the context of war, though again what constitutes a 'war environment' is debatable. Terrorism, then, is about the use of violence or the credible threat of violence in order to generate a psychological impact beyond the immediate victims, whether they are civilian (or non-combatant) or not, or whether one sympathises with the cause or not.

\section{Implications}

One implication of this third assumption is that the phenomenon cannot then be conceptualized as the peacetime equivalent of a war crime. This is because acts of terrorism can then take place within war against combatants. In any case, and perhaps more fundamentally, such an 'equivalence' is also questioned by the fact that spreading fear beyond the immediate victims is not a necessary pre-requisite for something to be called a 'war crime' whereas it is for an act of terrorism. Thus, while it is possible to argue that the physical manifestation of those acts of terrorism that target civilians in peacetime may deem them to be the peacetime equivalent of war crimes, ${ }^{103}$ this overlooks the psychological dimension that is indispensable to terrorism.

A second implication of viewing terrorism as not just targeting civilians or non-combatants is the extent to which terrorism can then be conceptualized as an 'extranormal' form of political violence (however one defines 'extranormal'). In one of the earlier theoretical contributions

\footnotetext{
would suggest that it is a matter of scale. Terrorism and state terror, in my view, are separate phenomena (see Richards, Conceptualizing Terrorism (forthcoming)), with the latter being of a much larger scale than the former. It is therefore state terror (rather than terrorism) that I believe is more akin to psychological warfare (though one could argue that terrorism is a lower form of it).

100 The Economist, 'Green on Blue blues', September $1^{\text {st }} 2012$, available at:

http://www.economist.com/node/21561943 (accessed November 6th 2013).

${ }^{101}$ BBC News online, 'Afghan policeman kills three British soldiers', July $2^{\text {nd }} 2012$, available at: http://www.bbc.co.uk/news/uk-18670175 (accessed November 6th 2013).

${ }_{102}$ Indeed the outcome was to undermine attempts to train the Afghan forces with the US apparently suspending its training of new recruits to the Afghan police force (BBC News online, 'Afghanistan 'rogue' attack: Four US soldiers killed', September $16^{\text {th }} 2012$, available at: http://www.bbc.co.uk/news/world-asia-19614911 (accessed November 6th 2013).

103 Though this wouldn't be the case if one included acts of violence against property in a definition of terrorism.
} 
to the study of terrorism Thornton described the phenomenon as 'a symbolic act designed to influence political behaviour by extranormal means, entailing the use or threat of violence' and that 'terror lies beyond the norms of violent political agitation that are accepted by a given society' ${ }^{104}$ Crenshaw concurs with the view that 'terrorism differs from other instruments of violence in its "extranormality", ${ }^{105}$ while Wardlaw also argued that "It is the extranormal nature of the use of terror that distinguishes it from other forms of political violence. ${ }^{106}$ Schmid also writes of the terrorists' 'decidedly extra-normal violence'. ${ }^{107}$

The argument that acts of violence can still be terrorism if combatants are targeted, and that, further, some such acts may even be legal in the context of war (perhaps as a 'lower' form of psychological warfare), implies that some acts of terrorism are more 'extranormal' than others. Some forms may be deemed extremely extranormal - such as those that deliberately target civilians, and, in particular, children, such as the Beslan school massacre of 2004 - in this case in contravention of 'the powerful norm that non-majority age persons lack intellectual maturity and cannot be held accountable for political policies' ${ }^{108}$ It is also the case, however, that some acts of terrorism (such as those against combatants in the context of war, or against the military of oppressive states) may not in fact be seen as extranormal at all.

Terrorism can therefore take the form of targeting both non-combatants (however defined) and combatants and definitions of the phenomenon should reflect this. And such definitions should have sufficient scope for the possibility that some acts of terrorism are more 'shocking' or more 'extranormal' than others, and indeed, that some may actually elicit one's sympathy rather than condemnation depending on one's perspective. If the international community is understandably more concerned with acts of terrorism that target civilians than those that do not then it should be argued that this is but one form of terrorism that should receive priority in terms of response, rather than determining that civilian or non-combatant targeting be definitional of terrorism.

An additional related implication, then, is that there may be some terrorisms that one sympathises with. This is certainly not a new proposition but it does underpin a particular dilemma that has been apparent in the international community's response to terrorism - that is the paradoxical approach of at times explicitly declaring a zero-tolerance approach to terrorism in all of 'its forms and manifestations' and yet simultaneously exhibiting an implicit sympathy for some terrorisms - for example, those against oppressive regimes and that refrain from targeting civilians or non-combatants. ${ }^{109}$ What about, for instance, acts of terrorism that do not target civilians (or non-combatants) but are carried out in defence or pursuit of 'freedoms, rights and liberties ... [that] ... serve as the basis of the Charter of Fundamental

\footnotetext{
104 Thornton, T., 'Terror as a Weapon of Political Agitation', in Eckstein, H., (ed.), Internal War, CollierMacmillan, Toronto, 1964, p. 73-76.

105 Op. cit. Crenshaw, 'The concept of revolutionary terrorism', p. 384 (note 91).

106 Wardlaw, G., Political Terrorism, Cambridge University Press, 1990, Chapter 1: The Problem of Defining Terrorism, p. 10.

${ }^{107}$ Op. cit. Schmid, A., (ed.), The Routledge Handbook of Terrorism Research, p. 19 (note 6).

${ }^{108}$ Kelly, R., 'Is Terrorism Always Wrong?', Perspectives on Terrorism, Volume 1 (2007), Issue 1, p. 19, available at: http://www.terrorismanalysts.com/pt/articles/issues/PTv1i1.pdf (accessed November 6th 2013). ${ }^{109}$ See, for example, discussion in Op. cit. Carlile, A., The Definition of Terrorism (note 37).
} 
Rights of the European Union'? ${ }^{110}$ Saul, for example, considers that the international community might regard "some terrorist-type violence as "illegal but justifiable" ... where it was committed in the "collective defence of human rights". 111

In his deliberations over the definition of terrorism Lord Carlile noted that:

'Many people have represented to me that it should not be an offence to plot and perpetrate terrorism against oppressive regimes which act in breach of their international obligations, subject to the proviso that civilians and noncombatants are not deliberately targeted or foreseen as victims. ${ }^{112}$

While zero tolerance approaches against terrorism 'whoever the perpetrator', and 'whatever the motive ${ }^{113}$ might helpfully move us away from perpetrator or cause based conceptions of terrorism, they do not acknowledge that there are some 'terrorisms' that one might agree with. Would the United Kingdom and the United States, for example, object if acts of terrorism were carried out against troops loyal to the Assad regime in Syria, or against proregime militias such as the notorious Shabiha? Wasn't some of the activity of the Kosovan Liberation Army, from the 'Western' perspective, an example of 'good terrorism'? The KLA targeted Serbian military and police, often in its early days relying on hit and run targets that were designed to have a wider psychological impact by '[denting] the self-confidence and prestige of the Serbian Military', and [breaking] the myth of their invincibility. ${ }^{114}$ Nor should one use more 'positive' labels, like 'freedom fighting', for the same activity - freedom fighting refers to a goal whereas terrorism is an activity - and so, in this author's view, we should refute the view that "freedom fighters' [inverted commas added] who attack only combatants are not terrorists. ${ }^{, 15}$ To do so simply further entrenches terrorism as a derogatory label at the expense of analytical utility.

In other words a comprehensive (and more honest) definition of terrorism needs to incorporate the possibility of terrorism that one might sympathise with or even endorse as well as 'bad terrorism' and international approaches to the phenomenon arguably should reflect this. ${ }^{116}$ It is then, another question as to which forms of terrorism should merit more urgent response (ie. that which targets civilians or non-combatants). Any moral repugnance against some particularly brutal forms of the phenomenon should not deviate us from

\footnotetext{
${ }^{110}$ Op. cit. European Commission Sixth Framework Programme Project, 'Defining Terrorism', p. 89 (note 38).

${ }^{111}$ Saul, B., 'Defining Terrorism to Protect Human Rights', in Staines, D., (ed.), Interrogating the War on Terror: Interdisciplinary Perspectives, Cambridge Scholars Publishing, Newcastle (UK), 2007, p. 208.

112 Op. cit. Carlile, A., The Definition of Terrorism (note 37).

${ }^{113}$ Romanov, V., 'The United Nations and the Problem of Combatting International Terrorism', Terrorism and Political Violence', Terrorism and Political Violence, Volume 2, Autumn 1990, No. 3. p.297.

${ }^{114}$ Mulaj, K., 'Resisting an Oppressive Regime: The Case of Kosovo Liberation Army', Studies in Conflict \& Terrorism, Volume 31, No. 12, 2008, p. 1111.

${ }^{115}$ Enders, cited in op. cit. Schmid, A., (ed.), The Routledge Handbook of Terrorism Research, p. 20 (note 6).

116 The activities of the resistance movements (to nazi rule) in World War Two are often cited as examples. Schmid uses the hypothetical example where the seizure of the family of a genocidal dictator might be undertaken in order to prevent further genocide. Interestingly, this last example even allows for 'good terrorism' against civilians as a 'lesser evil' (depending upon how one defines civilians). (op. cit. Schmid, A., (ed.), The Routledge Handbook of Terrorism Research, p. 95 [note 6]).
} 
including the less contemptible (or even noble) forms from a general definition of the concept as a whole. For example, even if the French resistance did not target civilians when they carried out acts of violence against an oppressive and occupying (nazi) regime, they nevertheless, subject to the necessary criteria (in particular the intent to generate a psychological impact beyond the immediate victims), still carried out acts of terrorism. It is entirely understandable, if regrettable, that in the real world of domestic and international politics 'terrorism' is used selectively given its perjorative connotation in practice, and this is one of the fundamental challenges for more objective academic endeavours in conceptualizing terrorism (and a formidable barrier to being heard).

\section{Conclusion: defining terrorism and the empirical problem of proving intent}

If we are endeavouring to define terrorism, and if we argue that there is something different about terrorism that is common to all acts of terrorism (and that this is not civilian targeting or a peacetime environment, or indeed extranormal violence), then what is qualitatively distinctive about all forms of the phenomenon? While being open to the possibility that, as we have considered above, there may be nothing particular or intrinsic about it, the author ultimately concludes that what makes terrorism different to other forms of political violence is its primary purpose of generating a wider psychological impact beyond the immediate victims or object of attack. ${ }^{117}$ While warfare in general or state terror may at times have a similar purpose this is the sine qua non of terrorism. Primoratz makes the distinction clear: 'all uses of political violence effect some degree of fear', but in 'terrorism proper, the causing of fear and coercion through fear is the objective'. ${ }^{118}$ How then should we ultimately define the phenomenon? It has been said that '[t] he art of making a good definition is to include as few elements as possible but also as many as necessary'. ${ }^{119}$ Hence my definition is limited to simply this: terrorism is the use of violence or the threat of violence with the primary purpose of generating a psychological impact beyond the immediate victims or object of attack for a political motive. This, in my view is common to all acts of terrorism. If the primary aim is not to generate this wider psychological impact then it is not terrorism.

It might be argued that this definition is short of some key features of terrorism that are often included in the definitions of others. Yet, in the context of what I have argued above, many of these, such as civilian/non-combatant targeting, the use of 'extranormal' violence, or terrorism as illegitimate violence, cannot be considered to be definitional of terrorism. There may therefore be some merit in describing terrorism over and above defining it. ${ }^{120}$ This would allow us to draw attention to features of terrorism that 'often' or 'usually' apply but

\footnotetext{
${ }^{117}$ See note 99 in relation to a further discussion on the difference between terrorism and psychological warfare. The author suggests that state terror, rather than terrorism, is more akin to psychological warfare.

${ }_{118}$ Primoratz, I., cited in op. cit. English, R., Terrorism, How to Respond, p. 5 (note 4).

${ }^{119}$ Op. cit. Schmid, A., (ed.), The Routledge Handbook of Terrorism Research, p. 73 (note 6).

${ }^{120}$ See, for example, op. cit. Jackson, R., Jarvis, L., Gunning, J., and Breen Smyth, M., Terrorism, A Critical Introduction, pp. 115-20 (note 43).
} 
are not definitive of the concept. The Policy Working Group on the United Nations and Terrorism, for example, argued that: 'Without attempting a comprehensive definition of terrorism, it would be useful to delineate some broad characteristics of the phenomenon' ${ }^{121}$, and in 2004 the UN ad hoc Committee on terrorism referred to a 'recommended 'description' of terrorism. ${ }^{122}$ Describing terrorism, however, is not an alternative to defining or conceptualizing the phenomenon because it doesn't help us to classify what terrorism is or isn't, or to determine what its parameters are - this needs a definition.

A rarely acknowledged but formidable challenge arising from this author's (and many others') conceptualizations of terrorism is that it is extremely difficult to prove what constitutes an act of terrorism because it is hard to know what the intent or purpose is behind the act of violence. Roberta Senechal de la Roche argued that 'we evaluate a scientific definition solely by its usefulness in the ordering of facts. ${ }^{, 123}$ This clearly presents us with a problem - our definition, because it rests on intent, does not lend itself to the scrutiny of observable facts. Indeed, while there may be some cases where purported intent is expressed in relation to an act of political violence, this may not be the real intent and there are many more examples where we do not even have purported intent. How do we know, for example, whether wider psychological impact is the intent more than the physical effects of an act of violence?

Thus, there may have been many acts of violence that have been labelled terrorism when, by our definition, there is little evidence that they are. This opens up a whole new subjective debate - indeed, this is arguably where the real subjectivity problem lies within the definition of terrorism. In the face of limited evidence, how do we know (and who decides) if an act of political violence is primarily designed to generate a wider psychological impact over its physical effect? This is arguably the most fundamental problem with my conception of terrorism - and indeed, for some, it may justify the view that any serious endeavour to grapple with the definitional issue is indeed a waste of effort.

Perhaps we should simply define terrorism according to what is more readily observable in keeping with de la Roche's 'sole' function or purpose of a definition, and to exclude the core element of intent altogether - perhaps by focussing on tangibles such as incidents of the targeting of civilians (or non-combatants) in non-war environments (in keeping with international norms to do with the protection of civilians from any form of armed combat), and to gather data accordingly. But this compromises what this author, and many others, believe an act of terrorism to be. If we are comfortable with our conception of what terrorism

\footnotetext{
${ }^{121}$ Policy Working Group on the United Nations and Terrorism, quoted in op. cit. Schmid, A., (ed.), The Routledge Handbook of Terrorism Research, p. 56 (note 6).

${ }^{122}$ Op. cit. Schmid, A., (ed.), The Routledge Handbook of Terrorism Research, p.60 (note 6). It has been argued that there is sometimes confusion between definition and description with Vladimir Lukov (commenting on Schmid's academic consensus definition) arguing that the 'definition is rather a description than a definition', although he believed that "this "definition" is the most accurate description of the phenomenon in the literature' (Lukov, V., quoted in op. cit. Schmid, A., (ed.), The Routledge Handbook of Terrorism Research, p. 61 [note 6]).

${ }^{123}$ De la Roche, R., quoted in op. cit. Schmid, A., (ed.), The Routledge Handbook of Terrorism Research, p. 90 (note 6).
} 
is then the challenge is to empirically prove what acts constitute terrorism and which ones do not. There is unfortunately no simple answer to the problem of proving intent, to determine that the psychological dimension is the primary purpose behind an act of violence. Yet, there is also no escaping the fact that it is this psychological dimension, where the immediate victims are not the real target of the 'terrorist message', that conventional academic wisdom sees as the essence of terrorism. Terrorism as a method is about intended psychological impact beyond the immediate target over and above anything else, and one should not alter its meaning simply to accommodate what might be more readily and conveniently observable, hence 'the onus is upon the social scientist to establish intent'. ${ }^{124}$

${ }^{124}$ Claridge, D., 'State Terrorism? Applying a Definitional Model', Terrorism and Political Violence, Volume 8, No. 3, 1996, p. 51. 